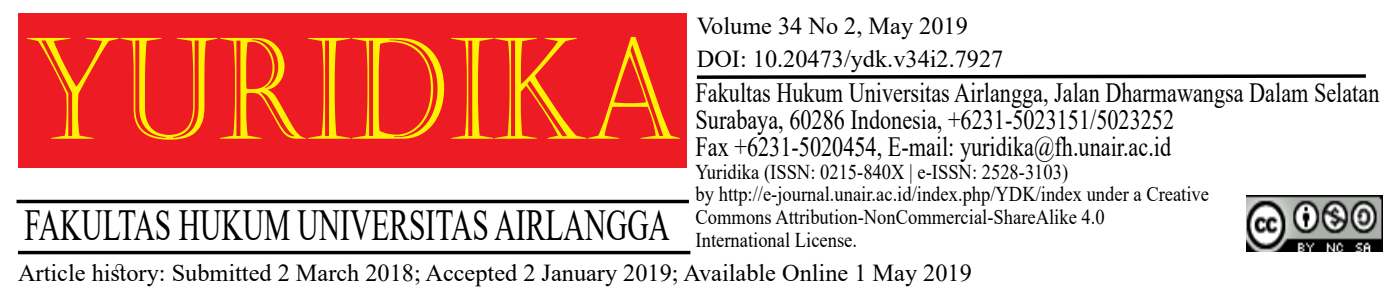

\title{
FDI on Tourism and the Environmental Damage: What Indonesia's Trade and Investment Agreements Can Do?
}

\author{
I Gusti Ngurah Parikesit Widiatedja \\ ngurahparikesit@gmail.com \\ Udayana University
}

\begin{abstract}
The existence of FDI on tourism has provided benefits, covering job opportunities, transfer of technology, government revenue, and the partnership with small and medium enterprises. However, FDI on tourism has also contributed to environmental damage in Indonesia. This paper is aimed to analyse whether trade and investment agreements that involve Indonesia can contribute to prevent and mitigate environmental damage as a result from FDI on tourism. This article is normative research, examining the existing trade and investment agreements that involve Indonesia and compare them with other countries' agreements. This paper argues that there is evidence to suggest that trade and investment agreements may incorporate provisions in order to ameliorate environmental harm from the existence of FDI on tourism. However, Indonesia has not incorporated any such provisions in its own agreements. Hence, this paper explains that there will be three suggestions to be considered, namely: Indonesia should start putting environmental concern under its trade schedule; Indonesia should consider opening environmental services; and Indonesia should start putting environmental concern in its investment agreements.
\end{abstract}

Keywords: Foreign Direct Investment on Tourism; Environmental Damage; Trade and Investment Agreements.

\section{Introduction}

Some studies showed that Foreign Direct Investment (FDI) had provided positive impacts for host countries across the globe. These impact encompassing the increase of job opportunities, ${ }^{1}$ the rise productivity and export capacity, ${ }^{2}$

${ }^{1}$ Julian Richards and Elizabeth Schaefer, 'Jobs Attributable to Foreign Direct Investment in the United States' (International Trade Administration, the United States of America, 2016) <https:// www.trade.gov/mas/ian/build/groups/public/@tg_ian/documents/webcontent/tg_ian_005496. pdf.> accessed 2 March 2018.; Robert Lipsey and Fredrik Sjöholm, 'FDI and Growth in East Asia: Lessons for Indonesia’ (2010) 852.[20].; I Gusti Ngurah Parikesit Widiatedja, Liberalisasi Jasa Dan Masa Depan Pariwisata Kita (Udayana University Press 2010).[46].

2 Jens M Arnold and Beata S Javorcik, 'Gifted Kids or Pushy Parents? Foreign Direct Investment and Plant Productivity in Indonesia' (2009) 79 Jens M Arnold and Beata S Javorcik.[48]. 
and the growth of wider distribution channel for local firms. ${ }^{3}$ Similarly, FDI on tourism has also contributed huge benefits. Some studies then denoted how FDI on tourism have provided more jobs as tourism is more labor-created than agricultural sectors, ${ }^{4}$ involving more semi-skilled and low-skilled employees. ${ }^{5}$ Other benefits surprising the rise of tourism's value chain, the increase of government revenue, the rise of transfer of technology, and the increase of partnership with small and medium firms.

Although providing significant benefits, some studies then showed the adverse impacts of FDI on tourism on environment. Firstly, there has been an indication of what has been called as the 'pollution haven hypothesis' wherein some firms tended to migrate from countries 'strict environmental standards to countries' flexible environmental standards, gaining a benefit from weak environmental regulations. ${ }^{6}$ In addition, some foreign firms on hotel will harm the environment more than local hotels because they are typically bigger and more luxurious, using more resources, including water and energy than local hotels. ${ }^{7}$ Some empirical studies (which discuss later on this paper) support how the environmental damage has taken place as the detrimental effect of FDI on tourism.

Managing the environmental damage from the existence of FDI on tourism, states can promulgate national and local laws and policies, preventing and mitigating such impact on a particular country and location. These measures would be more effective if it is supported by international agreements on trade and investment. In Indonesia, the presence of FDI on tourism is regulated under trade and investment agreements. In trade agreements, the General Agreement on Trade in Services

\footnotetext{
${ }^{3}$ Huiya Chen and Deborah L Swenson, 'Multinational Exposure and the Quality of New Chinese Exports' (2014) 76 Oxford Bulletin of Economics and Statistics.[56].

${ }^{4}$ Jonathan Mitchell and Caroline Ashley, Pathways to Prosperity-How Can Tourism Reduce Poverty: A Review of Pathways, Evidence and Methods (World Bank 2007).[49].

${ }^{5}$ United Nations Conference on Trade and Development, 'The Contribution of Tourism to Trade and Development' (Trade and Development Board, 2010) <https://unctad.org/en/Docs/cid8_ en.pdf $>$ accessed 11 February 2018.

${ }^{6}$ Daniel Bethlehem,[et.,al.], The Oxford Handbook of International Trade Law (Oxford University Press 2009).[511].

${ }^{7}$ I Gusti Ngurah Parikesit Widiatedja, 'Retire in Paradise: Urgensi Pengaturan Pariwisata Pensiunan (Retirement Tourism) Di Indonesia’ (2018) 11 Arena Hukum.[2].
} 
(GATS) has obliged Indonesia to launch its schedule, comprising which sectors in tourism are opened for FDI. ${ }^{8}$ In investment agreements, Indonesia has involved in many international investment agreements (IIAs), including preferential trade agreements with investment provision and bilateral investment treaties (BITs). ${ }^{9}$ All those investment agreements have a primary goal to promote and to protect the existence of FDI within Indonesia's territory.

This paper is aimed to analyse whether trade and investment agreements that involve Indonesia can contribute to the prevention and the mitigation of adverse impact of FDI on tourism on the environment. This paper argues that there is evidence to suggest that trade and investment agreements may incorporate provisions in order to ameliorate the environmental damage from the existence of FDI on tourism. However, Indonesia has not incorporated any such provisions in its own agreements.

This paper starts by showing the existence of FDI on tourism in Indonesia, explaining the FDI's theory and definition, the FDI's benefits on tourism and the FDI's adverse impacts on tourism on the environment in Indonesia. This paper then examines what Indonesia's trade and investment agreements can do to manage the adverse impact of FDI on tourism. There will be three suggestions to be considered, namely: Indonesia should start putting environmental concern under its GATS schedule; Indonesia should consider opening environmental services; and Indonesia should start putting environmental concern in its investment agreements. All those explanations will be analysed by looking at other countries' trade and investment agreements.

${ }^{8}$ I Gusti Ngurah Parikesit Widiatedja, Kebijakan Liberalisasi Pariwisata: Konstruksi Konsep, Ragam Masalah Dan Alternatif Solusi (Udayana University Press 2011).[53].

${ }^{9}$ See Agreement Between the Government of Australia and the Government of the Republic of Indonesia concerning the Promotion and Protection of Investments, signed 17 November 1992 (entered into force 29 July 1993') art V (“Indonesia-Australia BIT"); Agreement Between the Government of the Republic of Indonesia and the Government of the Federal Republic of Germany on the Promotion and Protection of Investments, signed 14 May 2003 (entered into force 2 June 2007) ("Indonesia-Germany BIT"). 


\section{The Existence FDI on Tourism In Indonesia}

\section{The Definition and the Theory FDI}

According to International Monetary Fund (IMF), FDI is investment activities that are undertaken to obtain what so-called 'lasting interest' in firms running overseas of the investor's economy. ${ }^{10}$ In more detailed, OECD has defined FDI as a kind of international investment where a investor in one particular country with the purpose of achieving a lasting interest in corporations in another country. ${ }^{11}$ The lasting interest leads to the presence of a lenghty-period relation between the firms an the direct investor, reflecting a huge level of effect by the direct investor on firms' administration. The possession of at minimum ten (10) percent of the mechanism of voting, showing the investor's authority, is the standard measurement employed. ${ }^{12}$

There has been a theory, explaining why firms would engage in FDI. Raymond Vernon initiated the 'Product Life-cycle' theory, enumerating four stages in which products were invented, produced, and sold..$^{13}$ The duration of each stage was decided by production cost, demand, and revenues. In the 'introduction' stage, materials and labour stipulated for products were from the location of its origination (such as the USA). ${ }^{14}$ At this stage, profits seemed to be low and products were aimed for domestic users. ${ }^{15}$ In the 'growth' stage, the product became widely branded and served a broader range of users. In the 'maturity' stage, foreign demands for the product raised, predominantly from developed countries. To meet these demands, firms might produce goods and services for export, license foreign producers, or participate in foreign direct investment in the countries where demand mostly available. ${ }^{16}$ In the 'decline' stage, products came their saturation levels, with the

\footnotetext{
${ }^{10}$ International Monetary Fund, 'The Balance of Payments Manual 5ed' (International Monetary Fund, 2018) <https://www.imf.org/external/np/sta/bop/BOPman.pdf > accessed 9 March 2018.

11 The Organization for Economic Cooperation and Development, 'OECD Benchmark Definition of Foreign Direct Investment 4ed' (OECD, 2008) <https://www.oecd.org/daf/inv/ investmentstatisticsandanalysis/40193734.pdf> accessed 11 March 2018.

${ }^{12}$ ibid.

${ }^{13}$ Raymond Vernon, 'International Trade and International Investment in the Product Cycle' (1966) 80 Quarterly Journal of Economics.[191].

${ }^{14}$ ibid.[196].

${ }^{15}$ Giancarlo Gandolfo, International Trade Theory and Policy (2nd edn, Springer 2014).[167].

16 ibid.
} 
curtailed of sales and income. ${ }^{17}$ Then, firms halted producing goods that were no longer economically viable. ${ }^{18}$ Firms might also consider locating production activities in other countries, particularly developing countries. ${ }^{19}$

The following theories denoted why countries have actively engaged in FDI. MacDougall initiated that whenever the free motion of capital took place from a home state to a host state, the marginal productivity of capital would be finally equalised between the two states. ${ }^{20}$ Feldstein and Horioka then elaborated that the motion of capital predominantly moved from a country that has a rich capital and low level of interest rate to a country that has a lower capital and higher level of interest. ${ }^{21}$ This process occurred until the capital stock and interest rates had reached it balance posture. After investing overseas, the home state's outcome tumbled without any downtrend in the national income because the home states earned higher income in the long term. ${ }^{22}$ Equally, the spillovers effects of the FDI also push a state to attract FDI. Generally speaking, the spillovers effects associated with the rise of domestic corporations' productivity as a result from the existence of foreign corporations. ${ }^{23}$ Technological improvement, management skills, and working advancement are the examples of the forms of spillovers.

\section{The Benefits of FDI on Tourism}

Globally, tourism has been key roles in economic matters, job opportunities, export income and domestic value added. Referring to United Nations World Tourism Organisation (UNWTO), tourism has contributed to 5.9 percent of employment,

\footnotetext{
${ }^{17}$ Christopher S Yoo, 'Product Life Cycle Theory and the Maturation of the Internet' (2010) 104 Northwestern University Law Review.[646].

${ }^{18}$ ibid.

${ }^{19}$ Giancarlo Gandolfo (n 15).Op.Cit [168].

${ }^{20}$ GDA MacDougall, 'The Benefits and Costs of Private Investment from Abroad: A Theoretical Approach' (1960) 36 Economic Record.[32].

${ }^{21}$ Martin Feldstein and Charles Horioka, 'Domestic Savings and International Capital Flows' (1980) 90 Economic Journal.[315].

${ }^{22}$ GDA MacDougall (n 23).Op.Cit.[27].

${ }^{23}$ Molly Lesher and Sébastien Miroudot, 'FDI Spillovers and Their Interrelationships with Trade' (2008) 80.[70].
} 
4.1 percent of GDP, and 21.3 percent of service exports to OECD states. ${ }^{24}$ Equally important, the arrivals of international tourist touched more than 1.1 billion in 2014, a rise of 4.2 percent on the prior year, having achieved the 1 billion mark in $2012 .{ }^{25}$

The existence of FDI on tourism has provided some benefits, especially for developing countries. There have been two impacts for reducing poverty. Firstly, the direct impact, covering the earnings and wages for those who directly work in tourism industries. ${ }^{26}$ International evidence denoted that FDI on tourism is more labor-created than other non-agricultural fields. ${ }^{27}$ Equally important, it has been a primary engine of employment, especially for low-skilled and semi-skilled employees. ${ }^{28}$ The FDI on tourism is also an significant source of government income. Finally, FDI on tourism has the ability to involved small and medium firms and local communities through various partnership programs, helping them to increase their competitiveness. ${ }^{29}$

\section{The Adverse Impact of FDI on Tourism}

Although tourism is the most liberalised sector under the GATS, especially on the mode 3 (commercial presence), there is little empirical study on the adverse impact of FDI on tourism. Dwyer and Forsyth (1994) claimed that the analysis of FDI effects on tourism has been neglected and has induced less consideration in the literature than what was expected. ${ }^{30}$ Next, Buckley and Geyikdagi (1996) pointed out that the difficulties in gaining information and data caused the analysis of FDI

${ }^{24}$ The Organization for Economic Cooperation and Development, 'OECD Tourism Trends and Policies 2016' (OECD, 2016) <http://dx.doi.org/10.1787/tour-2016-en> accessed 2 February 2018.

25 ibid.

${ }^{26}$ Jonathan Mitchell and Caroline Ashley, Pathways to Prosperity - How Can Tourism Reduce Poverty: A Review of Pathways, Evidence and Methods (World Bank 2007).[49].

27 ibid.

${ }^{28}$ United Nations Conference on Trade and Development, 'The Contribution of Tourism to Trade and Development' (Trade and Development Board, 2010) <http://unctad.org/en/Docs/cid8_ en.pdf $>$ accessed 11 February 2018.

${ }^{29}$ ibid.

${ }^{30}$ Larry Dwyer and Peter Forsyth, 'Foreign Tourism Investment: Motivation and Impact' (1994) 21 Annals of Tourism Research.[516]. 
on tourism has gained little attention. ${ }^{31}$ Meanwhile, UNCTAD (2007) stated that the complicated analysis of FDI on tourism associated with the character of tourism that is not a singular activity. ${ }^{32}$ Tourism consisted of many separated and related activities, covering culture, recreation, beverage and food, transportation, sports, accommodation, and conventions. ${ }^{33}$

Some experts, nevertheless, analysed the adverse impacts of FDI on tourism on the environment. Firstly, the adverse impact of FDI on tourism is associated with what has been widely known as the 'pollution haven hypothesis' ${ }^{34}$ In this situation, despite being debatable, some firms tended to migrate from states with strict environmental standards to states with flexible environmental standards, taking advantage from weak environmental policy. For example, parent firm may deliver old stuffs that it was not useful anymore under the tight environmental regulation in place in its advanced countries to its overseas affiliation in developing economy with more negotiable regulations. ${ }^{35}$ Equally, host countries may loosen their environmental standards and regulations as a means of attracting new FDI. ${ }^{36}$ Morever, host countries did not appropriately uphold domestic standards to preserve the existing FDI, claiming that the economic benefits through the existence of FDI will be a crucial factor in their development, implying the indifference of the environmental considerations. ${ }^{37}$

\footnotetext{
${ }^{31}$ Peter Buckley and Necla V Geyikdagi, 'Explaining Foreign Direct Investment in Turkey's Tourism Industry' (UNCTAD Research Notes, 1996) < http://unctad.org/en/docs/iteiitv5n3a5 en.pdf $>$ accessed 17 February 2018.

${ }^{32}$ United Nations Conference on Trade and Development, FDI in Tourism: The Development Dimension (United Nations 2007).[2].; I Gusti Ngurah Parikesit Widiatedja, 'Towards Liberalization of Services in ASEAN: Challenges and Opportunities of ASEAN Framework Agreement on Services (AFAS) on Tourism' (2012) 10 Indonesian Journal of International Law.[69].

${ }^{33}$ ibid.

${ }^{34}$ Daniel Bethlehem (n 6).Op.Cit.[511].

${ }^{35}$ United Nations World Tourism Organisation, General Guidelines for the Development of Foreign Direct Investment Indicators on the Tourism Sector (Department of Statistics and Economic Measurement of Tourism 2004).[166].

${ }^{36} \mathrm{ibid}$.

${ }^{37}$ Nick Mabey and Richard McNally, 'Foreign Direct Investment and the Environment: From Pollution Havens to Sustainable Development', World Wide Fund for Nature (UK Report 1999).[13].
} 
UNWTO (2004) $)^{38}$ analysed how FDI on tourism has negatively affected the environment owing to its dominant position compare to local companies. In some countries, including Indonesia, foreign firms such as hotels were in the dominant position so that the adverse consequences generated by FDI could be greater than those of local firms. ${ }^{39}$ In Bali, high rating hotels (4-star or 5-star hotel) are mostly FDI that some of them are a part of the international leading chain hotel. The higher of the rating of the hotels can lead to the higher the chance of environmental damages. Specifically, a study of Barrowclough $(2007)^{40}$ showed that foreign hotels will harm the environment more than local hotels as they are bigger and tend to usage more resources, including energy and water, than local hotel. ${ }^{41} \mathrm{~A}$ study from United Nations Environment Programme (UNEP) (2012) indicated if a high-scale hotel project that involved foreign ownership has had adverse consequences on biodiversity, such as land conversion, coral reefs and coastal wetlands. ${ }^{42}$

There have been some empirical studies, pointing out the adverse impact of FDI on tourism. Perrin $(2001)^{43}$ admitted how GATS has significantly increased FDI in tourism. However, putting Belek, Turkey as a case study, the increase of FDI has been followed by over-concentration in central locations of activity, leading to the misuse of other assets in the area. Specifically, the constructions of beachfront hotels along with the large number of tourists have negatively impacted on the fragile dune ecosystem. ${ }^{44}$

Equations (2002) also analysed how India's participation under international trade agreements (GATS) have affected small communities in Goa, India, putting two areas of Goa: the Chapora-Sinquerim and Miramar-Caranzalem, and two

\footnotetext{
${ }^{38}$ United Nations World Tourism Organisation (n 39).Op.Cit.[167].

39 ibid.

${ }^{40}$ Diana Barrowclough, 'Foreign Investment in Tourism and Small Island Developing States' (2007) 13 Tourism Economics.[622].

${ }^{41}$ ibid.

${ }^{42}$ United Nations Environment Programme and World Tourism Organization, Tourism in the Green Economy - Background Report (UNWTO 2012).[5].

${ }^{43}$ Mireille Perrin, 'Preliminary Assessment of the Environmental and Social Effects of Trade in Tourismz', WWF International (WWF International 2001).[46].

44 ibid.
} 
international hotel chains; the Marriott Goa and the Taj Fort Aguada Resort as a case study. The result of this study showed that the presence of FDI on hotels had a negative impact on sand dune ecosystems in the Goan coast. ${ }^{45}$ In addition, the improper waste management facilities had caused waste problems in Goa. ${ }^{46}$ Analysing the cause of this environmental damage, the study then explained how the GATS did not provide sufficient safeguards to protect the communities from adverse impacts of FDI in tourism. ${ }^{47}$ Furthermore, this study criticized India's tourism schedule under the GATS, stating that its schedule did not comprehensively accommodate the tourism development plan of India, specifically, Goa.

Turning now to the discussion of the adverse impacts of FDI on tourism on the environment in Indonesia, a study from the Ministry of Tourism along with International Labour Organization (2012) stated that there was a significant increase of the energy's consumption and water as well as waste production after the presence of luxurious tourism accommodation in some tourism areas in Indonesia. ${ }^{48} \mathrm{~A}$ report from the city of Balikpapan, East Kalimantan (2015) revealed that the increasing number of hotels in Balikpapan has led to the increase of solid waste volume as some hotels have not established yet integrated waste treatment plant. ${ }^{49}$

The following empirical studies put Bali as a case study as Bali has been the most popular tourism destination in Indonesia. Pratiwi $(2004)^{50}$ denoted that due to the lack of planning, the rapid growth of tourism facilities, such as hotels and restaurants was not followed by the establishment of public and private refuse, and

${ }^{45}$ Equations, Weighing the GATS on a Development Scale: The Case of Tourism in Goa, India (Equations 2003).[5].

${ }^{46}$ ibid. [19].

${ }^{47}$ ibid. [5].

${ }^{48}$ Ministry of Tourism and Creative Economy of the Republic of Indonesia in cooperation with the International Labour Organization, Strategic Plan Sustainable Tourism and Green Jobs for Indonesia (ILO 2012).[80].

${ }^{49}$ Badan Lingkungan Hidup Pemerintah Kota Balikpapan, Buku Laporan Status Lingkungan Hidup (SLHD) Kota Balikpapan Tahun 2015 (Badan Lingkungan Hidup Pemerintah Kota Balikpapan 2015).[61].

${ }^{50}$ Wiwik Dwi Pratiwi, 'Tourism and Built Environment Changes in Traditional Communities Kuta and Nusa Dua, Bali, Indonesia as the Case Studies' (The University of Sheffield 2004).[187]. 
energy and water supplies in Kuta, Badung, Bali. ${ }^{51}$ Along similar lines, Tang $(2004)^{52}$ then revealed that some hotels in Bali did not have proper solid waste management (SWM) that led to the environmental destruction in Bali. ${ }^{53}$ Parker $(2011)^{54}$ supported this study by stating that the development of tourism facilities has denigrated the ecosystem in Ubud, Gianyar because there was greater pressure on the water table and various fauna were forced to migrate. ${ }^{55}$ Then raised water scarcity problems with the failing of groundwater levels, salinity intruding and land subsiding as undeniable impacts from the massive development of tourism facilities in Bali. ${ }^{56}$

\section{The Unique Character of Tourism as a Business Sector}

Some tourism scholars explain how tourism differs with other businesses. ${ }^{57}$ Hence, investors who intend to participate in tourism business should take into account these differences. ${ }^{58}$ Looking at law's point of view, these uniqueness would affect on how the government at all levels should enact and execute regulations for FDI on tourism. ${ }^{59}$

As intangible products, tourism prioritises experience and memory that are impossible to be reused or reproduced. Likewise, the impression of consumption is felt to its full degree. ${ }^{60}$ Tourism combines attractions and amenities in the

51 ibid.

${ }^{52}$ Janeen Tang, 'A Case Study of a Hotel Solid Waste Management Program in Bali' (University of Waterloo 2004).[90]. See also I Gusti Ngurah Parikesit Widiatedja, Bunga Rampai Pemikiran Hukum Kontemporer (Udayana University Press 2010).[31].

${ }^{53}$ ibid.

${ }^{54}$ Gregory Stuart Parker, 'Living in Two Worlds: How Tourism Has Influenced the Balinese World View of Tri Hita Karana’ (Massey University 2011).[72].

${ }^{55}$ ibid.

${ }^{56}$ Stroma Cole, 'A Political Ecology of Water Equity and Tourism: A Case Study from Bali' (2012) 39 Annals of Tourism Research.[1241].

${ }^{57}$ Arvid Flagestad and Christine A. Hope, 'Scandinavian Winter: Antecedents, Concepts and Empirical Observations Underlying Destination Umbrella Branding Model' (2001) 56 Tourism Review.[12].

${ }^{58}$ I Gusti Ngurah Parikesit Widiatedja and I Gusti Ngurah Wairocana, 'Fragmented and Unclear Laws and Regulations of Foreign Direct Investment in Indonesian Tourism' (2018) 5 Padjajaran Journal of Law.[408-409].

${ }^{59}$ Annette Pritchard,[et.,al]. Destination Branding - Creating the Unique Destination Proposition (Butterworth-Heinemann 2002).[408-409].

${ }^{60}$ ibid. 
hosting country, ${ }^{61}$ encompassing both intangible and tangible and intagible factors, including, among other things: catering, accommodation, transportations, and the openness of the local communities that are complement and inseparable each other. ${ }^{62}$ From economic perspective, tourism's production is not completed until the product reaches the final consumer. Tourism is perishable because the production and the consumption occur at the same time, and at the same place. ${ }^{63} \mathrm{Next}$, there is a seasonality of tourism demand where the tourism's demand is categorized by an irregular temporal supply. Every year, there are peak and low seasons where this pattern is different from destination to destination and country to country. ${ }^{64}$

Human resources determine the quality of tourism, particularly because the communication between the customer and the staff describes quality's perception. ${ }^{65}$ The approach of the staff is a salient factor to serve tourism's products. Another unique character is that the tourism's actors are in a dissimilar position, for instance, with Disney World in Orlando, in which one sole corporation is tremendously greater than any of other corporations running within the tourism's area ${ }^{66}$

Finally, the connection between tourism and other policy areas including the economy, infrastructure, transportation, planning, localand culture, is the last unique element of tourism. For example, monetary rule influences exchange rates, impacting the demand of international tourist, and its foreign exchange income. Domestic tourism actions can induce international of trade payments' balance. Equally, transportation rule can act as a means of shifting to more eco-friendly transport choices. ${ }^{67}$

\footnotetext{
${ }^{61}$ Arthur John Burkart and S. Medlik, Tourism. Past, Present and Future (Heinemann 1974). [206].

${ }^{62}$ J.R. Brent Ritchie and Robin J.B. Ritchie, 'The Branding of Tourism Destinations - Past Achievements and Future Challenges', the 1998 Annual Congress of the International Association of Scientific Experts (the International Association of Scientific Experts 1998).[111-9].

${ }^{63}$ Peter U.C Dieke, 'Tourism in Sub Saharan Africa: Production-Consumption Nexus'

(2013) 16 Current Issues Tourism.[626].

${ }^{64} \mathrm{ibid}$.

65 Jane Stacey, 'Supporting Quality Jobs in Tourism' (OECD Tourism Papers, 2015) <http:// dx.doi.org/10.1787/5js4rv0g7szr-en> accessed 22 August 2018.

66 J.R. Brent Ritchie and Robin J.B. Ritchie (n 96).Op.Cit.[25].

${ }^{67}$ Peter Haxton, 'A Review of Effective Policies for Tourism Growth' (OECD Tourism Papers, 2015) <http://dx.doi.org/10.1787/5js4vmp5n5r8-en> accessed 23 August 2018.
} 


\section{What Indonesia'Trade And Investment Agreements Can Do Indonesia Should Start Putting Environmental Concern in its GATS Schedule}

There is evidence to advise that trade agreements may incorporate provisions in order to ameliorate environmental harm from the existence of FDI on tourism. However, Indonesia has not included any such provisions in its own agreements. Indonesia's schedule under the GATS (especially in mode 3) allowed the presence of FDI on tourism in Indonesia. This schedule potentially contributes to environmental damage associated with FDI on tourism because it has not yet put any concern to national interest or public interest that justifies the government to impose measures in order to protect those interests, including the environment. ${ }^{68}$

This paper will show how other members of the WTO have expressly put their national interests in their schedules under the GATS. They can deny FDI approval if it will conflict or jeopardise national or public interest. Furthermore, they can impose measures for protecting those interests, including environmental issue if the presence of FDI within their territories will cause detrimental impacts.

In Australia's schedule, especially in its horizontal commitments, every commercial presence or FDI proposals is examined under "Australia's foreign investment policy guidelines and the Foreign Acquisitions and Takeovers Act 1975 ... and are approved unless national interest considerations arise". ${ }^{69}$ In Malaysia's schedule, FDI's acceptance is usually given. However, it might be refused in the situation wherein the proposed investment conflicts with state's interest. ${ }^{70}$

Some WTO members have gone further by putting a particular concern on FDI in tourism to protect what they have categorised as economic, social and environmental interest. In European Communities schedule in tourism stated that FDI authorisation "can be denied in order to protect areas of particular historic and artistic interest" in Spain, Portugal, and Greece. ${ }^{71}$ Meanwhile, in Italy, a

${ }^{68}$ Schedule of Specific Commitments: Indonesia, WTO Doc SOC GATS SC/43 (15 April 1994).

${ }^{69}$ Schedule of Specific Commitments: Australia, WTO Doc SOC GATS/SC/6 (15 April 1994).

${ }^{70}$ Schedule of Specific Commitments: Malaysia, WTO Doc SOC GATS/SC/52 (15 April 1994).

${ }^{71}$ Schedule of Specific Commitments: European Communities and their Member States, WTO Doc SOC GATS/SC/31 (15 April 1994). 
local economic needs test has to be done before opening of new bars, cafés and restaurants that owned by foreigners. ${ }^{72}$ There is a WTO member that expressly stated in its schedule how FDI in tourism should be undertaken in order to avoid environmental damage. Mexico's tourism schedule prohibited FDI to directly own the land and water "in a $50 \mathrm{~km}$. strip on the coastline and $100 \mathrm{~km}$. strip along the frontiers". ${ }^{73}$

Although some WTO members have put environmental concern in their schedules, there are no further studies yet, analysing how these measures are effective or useful for assisting host governments to mitigate any environmental harm from the presence of FDI (mode 3 GATS). Under the WTO jurisprudence, both panel and appellate body have not discussed yet the inclusion of national interest's concern, especially related to environmental measures under GATS schedule.

\section{Indonesia Should Consider to Open Environmental Services in its GATS}

\section{Schedule}

Beside the absence of environmental concern, Indonesia's schedule under the GATS has not opened yet the presence of FDI in environmental services. The inclusion of environmental services in the GATS' schedule reflected how WTO members have anticipated the potential negative impacts of trade liberalisation on the environment. The presence of FDI (especially from developed countries) that, to some extent, have more sophisticated technology and skill than domestic companies, should be balanced by the presence of FDI on environmental services in order to assist host countries as the government or domestic environmental services may not be able to effectively mitigate any adverse impacts after the presence of FDI. The absence of foreign environmental services in Indonesia then may contribute to the environmental damages, especially after the presence of huge-scale tourism projects and activities, involving FDI in Indonesia.

${ }^{72}$ Schedule of Specific Commitments: European Communities and their Member States, WTO Doc SOC GATS/SC/31 (15 April 1994).

${ }^{73}$ Schedule of Specific Commitments: Mexico, WTO Doc SOC GATS/SC/56 (15 April 1994). 
Some scholarly articles then explained the importance of environmental services for host countries in order to anticipate environmental damages. Hoad ${ }^{74}$ argued that the presence of foreign environmental services will assist host governments strengthen environmental standards by promoting better competition. Similarly, Knigge and Nuffort ${ }^{75}$ illustrated the presence of environmental services as a 'win-win solution' wherein the economic profits of trade liberalisation and the aims of sustainable development can be attained at the same time. They then pointed out a number of environmentally harmful services, such as transport, tourism, and oil exploration services should be followed by the presence of highquality environmental services. ${ }^{76}$

Compare to other WTO members, Australia, Finland, Hungary, Slovakia, South Africa, and Turkey, that intensively develop tourism, have included environmental services in their schedules, covering sewage services, sanitation, refuse disposal services, and similar services. Some other WTO members have gone further by putting other environmental services (other than sewage, refuse disposal, and sanitation) in their schedules. Bulgaria added noise pollution monitoring services, monitoring services of exhaust gases, and nature protection services in its schedule. ${ }^{77}$ Colombia then opened FDI for Environmental impact studies. ${ }^{78}$ Next, Japan, ${ }^{79}$ and European Communities $^{80}$ included nature and landscape protection services, noise abatement services, and cleaning services of exhaust gases. ${ }^{81}$ Lastly, Thailand's schedule covered hazardous waste management, air pollution and noise management, consultancy on sewage system, and other environmental management services. ${ }^{82}$

\footnotetext{
${ }^{74}$ Darren Hoad, 'The General Agreement on Trade in Services (GATS) and Its Impact on Sustainable Tourism' (2002) 13 Anatolia: An International Journal of Tourism and Hospitality Research.[115].

${ }^{75}$ Markus Knigge and Caroline Nuffort, Report on Trade, Environment, and Trade in Services (Concerted Action on Trade and Environment 2005).[5].

76 ibid.

${ }^{77}$ Schedule of Specific Commitments: Bulgaria, WTO Doc SOC GATS/SC/122 (21 May 1997).

${ }^{78}$ Schedule of Specific Commitments: Colombia, WTO Doc SOC GATS/SC/20 (15 April 1994).

${ }^{79}$ Schedule of Specific Commitments: Japan WTO Doc SOC GATS/SC/46 (15 April 1994).

${ }^{80}$ Schedule of Specific Commitments: European Communities and their Member States, WTO Doc SOC GATS/SC/31 (15 April 1994).

${ }^{81}$ Schedule of Specific Commitments: Norway WTO Doc SOC GATS/SC/66 (15 April 1994).

${ }^{82}$ Schedule of Specific Commitments: Thailand WTO Doc SOC GATS/SC/85 (15 April 1994).
} 


\section{Indonesia should Start Putting Environmental Concern in its Investment Agreements}

The existence of FDI on tourism in Indonesia is not only regulated under the GATS, but also international investment agreements. The role of the latter has been increasingly significant as Indonesia has concluded agreements, covering tourism. Specifically, Indonesia has concluded preferential trade agreements (PTAs) that include investment chapters, such as AFTA and ASEAN-Japan FTA although investment has traditionally been covered by Bilateral Investment Treaties (BITs).

Muchlinski (2008) showed how investment agreements seemed to only pursue economic benefits, neglecting the impact of certain adverse impacts. ${ }^{83}$ Thus, it is crucial to stabilise the investors' interest, including transparent and predictable investment regulations and the host countries' interests to achieve its development goals, such as a 'right to regulate' for policy purposes, especially environmental concern. ${ }^{84}$ UNCTAD suggested that IIAs should not only accomodate the goals of investment liberalization and protection, but also the goals that enable host countries to mitigate any adverse environmental implications. ${ }^{85}$ This mechanism then can be realised through the incorporation of environmental concern both in the preamble and provision in the existing IIAs.

There has been a revolutionary motion, pointing how the environmental concerns in IIAs have risen since the mid 1990s. Looking from 2002, almost 89 percent of new investment agreements expressly put environmental concerns in their provisions. Indonesia, however, did not join this tendency. Along with Egypt, Indonesia has only one investment agreement with the environmental concern. This lack of environmental concerns in Indonesia's BITs may lead to problems when the government intends to prevent and mitigate any environmental harm

\footnotetext{
${ }^{83}$ Peter Muchlinski, 'Policy Issues' in Federico Ortino and Christoph Schreuer Peter Muchlinski (ed), The Oxford Handbook of International Investment Law (Oxford University Press 2008).[12].

${ }^{84}$ ibid.[15].; United Nations Conference on Trade and Development, Investment Policy Framework for Sustainable Development (United Nations 2015).[30].

${ }^{85}$ ibid. [30].
} 
from FDI projects, and to enact policy if the existence of FDI within Indonesia's territory has adversely affected the environment, reflecting the failure to protect Indonesia's national interest. ${ }^{86}$

Looking at other countries' practices, they have included environmental considerations in the preamble of their agreements. Specifically, the US-Uruguay BIT explained that the parties intended to reach the economic objective in comply with, among other things, environmental protection. ${ }^{87}$ Next, the preamble of the Economic Partnership Agreement between the Cariforum States and the European Community ('EC-CARIFORUM EPA') recognised the objective of the parties to the promotion of social and economic advancement in comply with the principle of sustainable development by implementing environmental protection. ${ }^{88}$

There have been some countries, putting environmental concern in their investment agreements' provisions. Article 21(2) Japan-Colombia BIT then explained that the parties can implement or uphold any measure in ensuring the activities of investment are conducted by not conflicting environmental law. ${ }^{89}$ Some countries have incorporated some additional stipulations as regards to environmental protection in their agreements. Specifically, Article 12(2) of the US Model BIT prohibited countries to relax environmental standards while attracting FDI by saying that it is unacceptable to promote investment by relaxing the environmental protection principle under domestic law. ${ }^{90}$

Some countries have shown how they have included environmental concerns in their agreements, both in the preambles and/or provisions, reflecting the balance

${ }^{86}$ I Gusti Ngurah Parikesit Widiatedja and I Gusti Ngurah Wairocana, 'The Lack of the Environmental Concern in Indonesia's Bilateral Investment Treaties' (2017) 3 Hasanuddin Law Review.[231].

${ }^{87}$ Treaty between the United States of America and the Oriental Republic of Uruguay concerning the Encouragement and Reciprocal Protection of Investment, signed 4 November 2005 (entry into force 1 November 2006) [the preamble].

${ }^{88}$ Economic Partnership Agreement between the Cariforum States, of the one part, and the European Community and its Member States, of the other part, signed 15 October 2008 [ the preamble].

${ }^{89}$ Agreement between Japan and the Republic of Colombia for the Liberalization, Promotion and Protection of Investment, signed 12 September 2011 (not yet in force) [art 21(2)].

${ }^{90}$ The United States Model BIT (2012) [art. 12 (2)]. 
between rights and obligations of states and investors. These measures, however, have not been tested yet, especially through international tribunals decision (such as investor-state dispute settlement) whether they are really effective to anticipate any adverse impact of FDI on the environment.

\section{Conclusion}

It has to be admitted that the existence of FDI on tourism has provided more employments because it involves more semi-skilled and low-skilled employees. FDI on tourism can also enhance tourism's value chain, government revenue, the rise of transfer of technology, and the increase of partnership with small and medium firms. Despite providing significant benefits, some studies then showed the adverse impacts of FDI on tourism on environment.

Managing the adverse impact of FDI on tourism on the environment, trade and investment agreements may incorporate provisions in order to ameliorate the environmental harm because of FDI on tourism. However, Indonesia has not included any such provisions in its own agreements. The absence of this provision could impede the government goals to impose masures in relation to the prevention and the mitigation of environmental damage as a result from FDI on tourism. Looking at other countries' practices, there will be three suggestions to be considered, namely: Indonesia should start putting environmental concern under its GATS schedule; Indonesia should consider opening environmental services within its territory; and Indonesia should start putting environmental concern in its investment agreements.

\section{Bibliography}

Agreement between Japan and the Republic of Colombia for the Liberalization, Promotion and Protection of Investment, signed 12 September 2011 (not yet in force).

Annette Pritchard, Destination Branding - Creating the Unique Destination Proposition (Butterworth-Heinemann 2002). 
Arthur John Burkart and S. Medlik, Tourism. Past, Present and Future (Heinemann 1974).

Christopher S Yoo, 'Product Life Cycle Theory and the Maturation of the Internet' (2010) 104 Northwestern University Law Review.

Daniel Bethlehem,[et.,al.], The Oxford Handbook of International Trade Law (Oxford University Press 2009).

Darren Hoad, 'The General Agreement on Trade in Services (GATS) and Its Impact on Sustainable Tourism' (2002) 13 Anatolia: An International Journal of Tourism and Hospitality Research.

Diana Barrowclough, 'Foreign Investment in Tourism and Small Island Developing States' (2007) 13 Tourism Economics.

Economic Partnership Agreement between the Cariforum States, of the one part, and the European Community and its Member States, of the other part, signed 15 October 2008.

Equations, Weighing the GATS on a Development Scale: The Case of Tourism in Goa, India (Equations 2003).

GDA MacDougall, 'The Benefits and Costs of Private Investment from Abroad: A Theoretical Approach' (1960) 36 Economic Record.

Giancarlo Gandolfo, International Trade Theory and Policy (2nd edn, Springer 2014).

Huiya Chen and Deborah L Swenson, 'Multinational Exposure and the Quality of New Chinese Exports' (2014) 76 Oxford Bulletin of Economics and Statistics.

I Gusti Ngurah Parikesit Widiatedja, Bunga Rampai Pemikiran Hukum Kontemporer (Udayana University Press 2010).

_- Liberalisasi Jasa Dan Masa Depan Pariwisata Kita (Udayana University Press 2010).

_- Kebijakan Liberalisasi Pariwisata: Konstruksi Konsep, Ragam Masalah Dan Alternatif Solusi (Udayana University Press 2011).

—_, 'Towards Liberalization of Services in ASEAN: Challenges and Opportunities of ASEAN Framework Agreement on Services (AFAS) on Tourism' (2012) 10 Indonesian Journal of International Law. 
— Tourism) Di Indonesia' (2018) 11 Arena Hukum.

I Gusti Ngurah Parikesit Widiatedja and I Gusti Ngurah Wairocana, 'The Lack of the Environmental Concern in Indonesia's Bilateral Investment Treaties' (2017) 3 Hasanuddin Law Review.

__, 'Fragmented and Unclear Laws and Regulations of Foreign Direct Investment in Indonesian Tourism' (2018) 5 Padjajaran Journal of Law.

International Monetary Fund, 'The Balance of Payments Manual 5ed' (International Monetary Fund, 2018) <https://www.imf.org/external/np/sta/bop/BOPman. pdf $>$ accessed 9 March 2018.

J.R. Brent Ritchie and Robin J.B. Ritchie, 'The Branding of Tourism Destinations Past Achievements and Future Challenges', the 1998 Annual Congress of the International Association of Scientific Experts (the International Association of Scientific Experts 1998).

Janeen Tang, 'A Case Study of a Hotel Solid Waste Management Program in Bali' (University of Waterloo 2004).

Jane Stacey, 'Supporting Quality Jobs in Tourism' (OECD Tourism Papers, 2015) $<$ http://dx.doi.org/10.1787/5js4rv0g7szr-en> accessed 22 August 2018.

Jens M Arnold and Beata S Javorcik, 'Gifted Kids or Pushy Parents? Foreign Direct Investment and Plant Productivity in Indonesia' (2009) 79 Jens M Arnold and Beata S Javorcik.

Jonathan Mitchell and Caroline Ashley, Pathways to Prosperity-How Can Tourism Reduce Poverty: A Review of Pathways, Evidence and Methods (World Bank 2007).

_- Pathways to Prosperity - How Can Tourism Reduce Poverty: A Review of Pathways, Evidence and Methods (World Bank 2007).

Julian Richards and Elizabeth Schaefer, 'Jobs Attributable to Foreign Direct Investment in the United States' (International Trade Administration, the United States of America, 2016) <https://www.trade.gov/mas/ian/build/ groups/public/@tg_ian/documents/webcontent/tg_ian_005496.pdf.> accessed 2 March 2018.

Khrisnamurti, 'Dampak Pariwisata Terhadap Lingkungan Di Pulau Tidung Kepulauan Seribu' (2016) 21 Kajian. 
Larry Dwyer and Peter Forsyth, 'Foreign Tourism Investment: Motivation and Impact' (1994) 21 Annals of Tourism Research.

Markus Knigge and Caroline Nuffort, Report on Trade, Environment, and Trade in Services (Concerted Action on Trade and Environment 2005).

Martin Feldstein and Charles Horioka, 'Domestic Savings and International Capital Flows' (1980) 90 Economic Journal.

Ministry of Tourism and Creative Economy of the Republic of Indonesia in cooperation with the International Labour Organization, Strategic Plan Sustainable Tourism and Green Jobs for Indonesia (ILO 2012).

Mireille Perrin, 'Preliminary Assessment of the Environmental and Social Effects of Trade in Tourismz', WWF International (WWF International 2001).

Molly Lesher and Sébastien Miroudot, 'FDI Spillovers and Their Interrelationships with Trade' (2008) 80.

Nick Mabey and Richard McNally, 'Foreign Direct Investment and the Environment: From Pollution Havens to Sustainable Development', World Wide Fund for Nature (UK Report 1999).

Peter Buckley and Necla V Geyikdagi, 'Explaining Foreign Direct Investment in Turkey's Tourism Industry' (UNCTAD Research Notes, 1996) <http://unctad. org/en/docs/iteiitv5n3a5_en.pdf $>$ accessed 17 February 2018.

Peter Forsyth and Larry Dwyer, 'Foreign Investment in Australian Tourism: A Framework for Analysis' (2003) 14 The Journal of Tourism Studies.

Peter Haxton, 'A Review of Effective Policies for Tourism Growth' (OECD Tourism Papers, 2015) <http://dx.doi.org/10.1787/5js4vmp5n5r8-en $>$ accessed 23 August 2018.

Peter Muchlinski, 'Policy Issues' in Federico Ortino and Christoph Schreuer Peter Muchlinski (ed), The Oxford Handbook of International Investment Law (Oxford University Press 2008).

Peter U.C Dieke, 'Tourism in Sub Saharan Africa: Production-Consumption Nexus' (2013) 16 Current Issues Tourism.

Raymond Vernon, 'International Trade and International Investment in the Product Cycle' (1966) 80 Quarterly Journal of Economics.

Robert Lipsey and Fredrik Sjöholm, 'FDI and Growth in East Asia: Lessons for 
Indonesia' (2010) 852.

Stroma Cole, 'A Political Ecology of Water Equity and Tourism: A Case Study from Bali’ (2012) 39 Annals of Tourism Research.

The Organization for Economic Cooperation and Development, 'OECD Benchmark Definition of Foreign Direct Investment 4ed' (OECD, 2008) <https://www. oecd.org/daf/inv/investmentstatisticsandanalysis/40193734.pdf $>$ accessed 11 March 2018.

—, 'OECD Tourism Trends and Policies 2016' (OECD, 2016) <http://dx.doi. org/10.1787/tour-2016-en> accessed 2 February 2018.

Treaty between the United States of America and the Oriental Republic of Uruguay concerning the Encouragement and Reciprocal Protection of Investment, signed 4 November 2005 (entry into force 1 November 2006).

Treaty between the Swiss Confederation and the Republic of Kosovo concerning the Encouragement and Reciprocal Protection of Investment, signed 27 October 2011 (entered into forced 13 June 2002).

United Nations Conference on Trade and Development, FDI in Tourism: The Development Dimension (United Nations 2007).

-, 'The Contribution of Tourism to Trade and Development' (Trade and Development Board, 2010) <https://unctad.org/en/Docs/cid8_en.pdf > accessed 11 February 2018.

- 'The Contribution of Tourism to Trade and Development' (Trade and Development Board, 2010) <http://unctad.org/en/Docs/cid8_en.pdf $>$ accessed 11 February 2018.

United Nations Environment Programme and World Tourism Organization, Tourism in the Green Economy - Background Report (UNWTO 2012).

United Nations World Tourism Organisation, General Guidelines for the Development of Foreign Direct Investment Indicators on the Tourism Sector (Department of Statistics and Economic Measurement of Tourism 2004).

—, 'UNWTO Tourism Highlights 2015 Edition' $(U N W T O, 2015)<$ http://www.eunwto.org/doi/pdf/10.18111/9789284416899> accessed 12 January 2018.

Widhayani Dian Pawestri, 'Keadilan Sosial Dalam Perlindungan Kepentingan Nasional Pada Penanaman Modal Asing Di Bidang Sumber Daya Alam' (2015) 30 Yuridika 
Wiwik Dwi Pratiwi, 'Tourism and Built Environment Changes in Traditional Communities Kuta and Nusa Dua, Bali, Indonesia as the Case Studies' (The University of Sheffield 2004)

HOW TO CITE: I Gusti Ngurah Parikesit Widiatedja, 'FDI on Tourism and the Environmental Damage: What Indonesia's Trade and Investment Agreements Can Do?' (2019) 34 Yuridika. 